\title{
Research on the Application of SQL Data Mining Technology in Logistics Enterprises Management
}

\author{
Weihai Xia ${ }^{1, a^{*}}$ and Shiping Liu $^{2, b}$ \\ ${ }^{1}$ Chengdu Normal University, Chengdu, Sichuan, 611130 \\ ${ }^{2}$ Chengdu Neusoft University, Chengdu, Sichuan, 611844 \\ a552733505@qq.com, 'Isp588@163.com
}

Keywords: SQL; Data mining technology; Logistics enterprise; Management application

\begin{abstract}
This paper mainly analyzed the process and function of data mining in logistics enterprise. Analyzed the data mining application in logistics enterprise customer relationship management, supply chain system management and decision- making system. Pointed out the means, effect and mechanism of SQL data mining technology in those applications. Finally took SQL data mining application in $\mathrm{Z}$ logistics enterprise as the example, introduced the process of data mining from analysis problems, preparing data, data mining and results.
\end{abstract}

\section{Introduction}

SQL data mining is an important development of computer data processing technology.

With the growth of logistics enterprise business data, digging and found huge amounts of complex business data is an important part of logistics enterprises daily management and business intelligence.

\section{Definition and Function of SQL Data Mining in Logistics Enterprise}

Definition of Logistics Enterprise Data Mining. Data mining in logistics enterprises can be stated as follows: Under the guidance of logistics enterprises operation target and business objectives, analyzed and process business data warehouse or data set in enterprise logistics services using various computer technology and data mining algorithm. In order to get hidden knowledge model and rule in the business data in the production and operation, optimize and perfect internal structure and management mechanism based on result of these business data mining, and support important business strategic decisions in logistics enterprise operation management.

Function of Data Mining in Logistics Enterprise. With supply chain information operations in modern logistics enterprise, continuous complex business data flow generated in every chain and link. Data mining of these massive amounts of information can help logistics enterprise found the operation rule and mode of business knowledge, and then improve the logistics enterprise's core competitiveness. Data mining in logistics enterprise mainly has three functions as follows: First, data mining can make the management of the logistics enterprises more differentiation and humanization. Second, data mining can make the logistics enterprise supply chain system more robust. The third, data mining can provide intelligent support for logistics enterprise business strategy.

\section{Application of SQL Data Mining in Logistics Enterprise CRM, SCM, and Decision-Making System}

In logistics enterprise production and management service market competition environment and information logistics operation environment, objectively need data mining technology to be introduced into the massive amounts of business data analysis, which speed up the business data analysis and improve the precision based on timely logistics service response mechanism. Customer relationship management (CRM), supply chain management (SCM) and decision system is the main 
field of SQL data mining technology in logistics enterprises. Table 1 is the project framework of SQL data mining technology in CRM, SCM and decision-making system of logistics enterprise.

Table 1 Project framework of SQL data mining technology in logistics enterprise

\begin{tabular}{|c|c|}
\hline \multirow{5}{*}{ CRM } & Logistics customer value segmentation \\
\hline & Logistics customer satisfaction analysis \\
\hline & Logistics customer loyalty analysis \\
\hline & Logistics customer churn analysis \\
\hline & Logistics business cross sales analysis \\
\hline \multirow{3}{*}{$\mathrm{SCM}$} & $\begin{array}{l}\text { Logistics strategic cooperative partner } \\
\text { selection }\end{array}$ \\
\hline & $\begin{array}{l}\text { Logistics alliance operation mode } \\
\text { improvement }\end{array}$ \\
\hline & \begin{tabular}{|llll}
$\begin{array}{l}\text { Logistics supply chain system risk } \\
\text { control }\end{array}$ & & & \\
\end{tabular} \\
\hline \multirow{4}{*}{$\begin{array}{l}\text { Logistics } \\
\text { Enterprise } \\
\text { Decision-m } \\
\text { aking } \\
\text { System }\end{array}$} & $\begin{array}{l}\text { Logistics business } \\
\text { decision-making }\end{array}$ \\
\hline & $\begin{array}{l}\text { Logistics financial } \\
\text { decision-making }\end{array}$ \\
\hline & $\begin{array}{l}\text { Logistics human } \\
\text { decision-making }\end{array}$ \\
\hline & Logistics CRM decision-making \\
\hline
\end{tabular}

Specific analysis is as follows:

Application of Data Mining in Logistics Enterprise Customer Relationship Management (CRM). Logistics customer value segmentation, logistics customer satisfaction analysis,

Logistics customer loyalty analysis, logistics customer churn analysis and logistics business cross sales analysis is the main application fields of SQL data mining technology in the logistics enterprise customer relationship management (CRM).

a. Logistics customer value segmentation is segmenting logistics enterprise customer using data mining method based on association rules, classification and clustering rules, classifying according to the characteristics of different business and trading behavior pattern. Which can help logistics enterprise to develop more diversity and targeted marketing strategy, put more resources on potential customers, and obtain logistics enterprises profit optimization.

b. Logistics customer satisfaction analysis, is finding the preference of different level, different scale and different qualities logistics customer on logistics service quality, through the analysis of the distribution information of the logistics customer feedback to the logistics enterprises customer service quality.

Then lead logistics enterprises adjust, add, modify, or cancel the service project.

c. Logistics customer loyalty analysis, is analyzing logistics customer trading business data, and find the relatively stable customer demand during a certain period, find the increasing and declining logistics enterprise service customer, and find out what kind of reason have led to this result, then make corresponding policy adjustments.

d. Logistics customer churn analysis, is mining the business data of customer who no longer have business or reduce large number of business with enterprises. From this we can find their own logistics service issues and the competitors' advantage on competitive strategy and product strategy, help logistics enterprise conduct marketing position and stabilize and develop more customers.

e. Logistics business cross sales analysis, refers to mining and discover the correlation of logistics service products logistics enterprise customers bought, and find out the key factors 
contributed to the customer purchase decision, thus to improve the logistics service mode and development.

Application of Data Mining in Logistics Enterprise Supply Chain Management (SCM). Modern logistics enterprise competition to some extent is the competition in supply chains, every mistake and sabotage of supply chain in enterprises will have loss on the chain. The data increasing in logistics enterprises with the performance of supply chain, which make data analysis and processing of the logistics business enterprise, cannot cope with, and the introduction of the SQL data mining technology solved the problem very well. Selection of logistics strategic cooperation partner, improving of logistics alliance operation mode and risk control of logistics supply chain system is the main application field of data mining in supply chain management.

a. Logistics strategic cooperative partner selection, is finding out competitive advantage and resources matching situation in logistics enterprises, through mining the history business data and resource endowment situation of logistics partners, and make a scientific and reasonable choice of logistics strategic partner.

b. Logistics alliance operation mode improvement, is analyzing every operation of logistics enterprise supply chain, through mining and analysis of the data supply chain logistics alliance operation mode and performance and related influencing factors, and improve the logistics alliance supply chain operation mode.

c. Logistics supply chain system risk control, is assessing the role of the node enterprises in supply chain and the uncertainty of supply chain operation through the correlation analysis of enterprise historical transaction data in the supply chain node, providing decision basis for related risk control, and realize minimum risk in the logistics supply chain system.

Application of Data Mining in Logistics Enterprise Decision-Making System. Data generated in modern logistics enterprise decisions field such as logistics business activities decision-making, logistics financial activities decision- making, logistics human resources management decision-making and logistics customer relationship management decisions-making, has been very difficult to effective control for the traditional analysis. Data mining technology based on strong computer analysis ability can extract useful business model from huge amounts of data, and enhance the scientific and speed of decision-making.

\section{Application of SQL Data Mining Technology in the Enterprise Management of $Z$ Logistics Enterprise}

Introduction of $\mathbf{Z}$ Logistics Enterprise. $Z$ logistics enterprise is a large logistics enterprise with annual output value of 1 billion CNY. The enterprise has 21 logistics distribution center in the main provinces and cities all over the country, mainly engaged in cargo transportation, warehousing, logistics information service, goods distribution, finance- transportation and other services. Z logistics enterprises has been among the first 100 national logistics enterprises and ranked no.34 in 2003. The fixed assets of $Z$ enterprise has reached 1.54 billion CNY, net assets of 1.12 billion yuan, has 457 logistics service network all over the country, all sizes of 7419 freight cars, and owns national networking computer information logistics system, some key core transportation equipment and shop reformed with GPS satellite positioning technology. With the enterprise development, huge amounts of business information data have increased dramatically, with daily decision-making requirements which traditional data processing methods unable to cope with. Enterprise made the according research, built daily management decision support system based on SQL data mining technology.

Process of SQL Data Mining in Z Logistics Enterprise. Choose Microsoft SQL Server 2000 tool set as the data mining software, which mainly including DTS component and Analysis Services tools. DTS is mainly responsible for converting data from the data source data warehouse. As is responsible for data mining and analysis.

Analyze Problems. Customer information in Z logistics enterprise is very huge and widespread, enterprise's logistics service project is facing greater competition in the market. So how to analyze 
the core high quality clients according to the business transaction service data and understand what they're focus on, is a urgent task for $\mathrm{Z}$ enterprise.

The basic tasks and goals of the data mining is to understand the key factors affecting logistics customer's purchasing behavior decision, focus on and track

The key significantly relationship, improve logistics customer service plan, and achieve the purpose of retaining old customers and developing new customers. This needs the correlation analysis of the data mining.

Prepare Data. After investigation, we found that the underlying database of $\mathrm{Z}$ enterprise information system is not compatible with SQL Server 2000.But the business data can be exported as the access database file, and SQL Server 2000 DTS components support import access database file into the SQL data warehouse or data mart, which preparing data source for business data mining.

Mining Data. Choose relation data mining model in SQL Server 2000 Analysis Service component, the same time, choose decision tree mining algorithm in the mining algorithm.

To the data for mining, do select option using structured query language (SQL) and SQL language, put this view as data source then do the eligible data mining, this model uses built-in algorithm and analyzes the data automatically.

Under the decision tree mining algorithm, the form result of data mining model is shown in Fig. 1.



Figure 1. Data mining result under decision tree model

Application Results. Analyze according to the mining results shown in Fig. 1, you can provide the necessary data support for related logistics business decisions. Through the integrated of correlative node and browsing under the different views we can obtain the intuitive understanding of the business data. According to AS mining reference data, color depth in chart is representing the degree of correlation between factors. Considering the problems of business secret, chart 1 shown in this paper is only a kind of symbolic similar graphics.

In the customer satisfaction analysis, with the expanding of the customer satisfaction node, we can find that the color shades of the elements which affect the customer satisfaction degree is different, the deeper the color, the greater impact on the customer satisfaction degree. Through the analysis of mining results, you can find four factors influence customer satisfaction, which including goods cost, transportation vehicle model, total cost and weight. Therefore, $\mathrm{Z}$ logistics enterprises can improve and enhance customer satisfaction based on the four factors.

\section{References}

[1] CHEN Yining. General Application of Data Mining Technology in Logistics Enterprises Management [J]. Journal of Guangxi Politics and Law Management Cadre Institute.2011 (02)

[2] XU Peipei, HE Yue. Regional Logistics Demand Forecasting based on Self-organizing Data Mining [J].Statistics and Decision Making.2011 (6) 
[3] YE Yuping. Application of Data Mining Technology in Logistics Industry [J]. Journal of Fujian Computer.2009 (05)

[4] LI Yihua, PANG Yan.Data Mining of Logistics Enterprises Work Process [J]. China Logistics and Purchasing.2009 (21)

[5] ZHAO Yuxiao, NI Zhiwei, Wang Yuan-yuan, WU Zhang-jun. SQL Server 2005 Data Mining Technology in the Application of Securities Customer Loyalty [J]. Computer Technology and Development.2010 (02)

[6] SUI LiPing, XU Chengtao, Li Rui-fang. Logistics System Design based on Data Mining Technology [J]. Microcomputer Information, 2009 (24)

[7] Zhijun Liu, Xiaowei Pu.The Analysis of Application of Data Mining Technology in the System of Intrusion Detection [C]. Proceedings of 2014 2nd International Conference in Humanities, Social Sciences and Global Business Management(ISSGBM 2014 V28)

[8] Xin-nan Zhao, Hong-chan Feng. Application of Data Mining Technology in the Enterprise Salary Design [C]. Proceedings of 2014 4th International Conference on Applied Social Science(ICASS 2014) Volume 51

[9] Guang-ming Yang, Xiao Feng, Kun Yang. Hydraulic metal structure health diagnosis based on data mining technology [J]. Water Science and Engineering, 2015 (04)

[10] Xu Lie. Analysis of developing the third party logistics enterprise in e-commerce age [C]. Proceedings of 2nd International Conference on Science and Social Research(ICSSR 2013)

[11] Yilei Pei, Wanxin Xue, Dandan Li, Yong Su. Research on Evaluation of Customer Experience of B2C Ecommerce Logistics Enterprises[C]. Proceedings of 2015 3rd International Conference on Education, Management, Arts, Economics and Social Science (ICEMAESS 2015) 